\title{
Studies on cellulase-ultrasonic assisted extraction technology for flavonoids from Illicium verum residues
}

Danna Huang ${ }^{1 \dagger}$, Xiaolei Zhou ${ }^{1,2+}$, Jianzhi $\mathrm{Si}^{1}$, Xiaomei Gong ${ }^{1,3}$ and Shuo Wang ${ }^{1,3^{*}}$

\begin{abstract}
Background: Illicium verum is widely cultivated in southern China especially in Guangxi province. Its fruits has been traditionally used in Chinese medicine. In recent years, it has been the industrial source of shikimic acid. Usually the residues after extracting shikimic acid are treated as waste. Thus, the aim of this study was to optimize the extraction conditions of cellulase-ultrasonic assisted extraction technology for flavonoids from I. verum residues.

Results: The optimum extraction conditions with a maximum flavonoids yield of $14.76 \%$ are as follows: the concentration of ethanol is $51.14 \%$, the liquid-solid ratio is $20.52 \mathrm{~mL} / \mathrm{g}$, the enzymatic hydrolysis pH is 5.303, the sonication time is $60 \mathrm{~min}$, the enzyme solution temperature is kept at $45^{\circ} \mathrm{C}$, the amount of added enzyme is $70 \mathrm{mg} / \mathrm{g}$, the enzymatic hydrolysis time is $2 \mathrm{~h}$ and the crushed mesh size is $0.355-0.85 \mathrm{~mm}$.
\end{abstract}

Conclusions: The data indicate that the cellulase-ultrasonic assisted extraction technology has the potential be used for the industrial production of flavonoids from I. verum.

Keywords: Cellulase-ultrasonic, Extraction, Flavonoid, Illicium verum

\section{Background}

Illicium verum Hook. f., known as Chinese star anise, is a magnoliaceae evergreen arbor plant that grows mainly in Southwest China, especially in the provinces of Guangxi, Guangdong, Yunnan and Fujian. China is already the world's largest producer of $I$. verum, with its cultivation as a medicinal plant in the Guangxi province accounting for approximately $90 \%$ of the total output [1-3]. As a kind of popular cooking spice, the dried fruits of $I$. verum have also been used traditionally in Chinese medicines. In 2002, I. verum was categorized as both food and medicine by the Ministry of Health, People's Republic of China and it is listed in the Chinese Pharmacopoeia with the actions of warming yang and dispelling cold, and regulating the flow of Qi to relieve pain [4-6]. The most valuable part of $I$. verum is the essential oil extracted

\footnotetext{
*Correspondence: ws428@163.com

${ }^{\dagger}$ Danna Huang and Xiaolei Zhou contributed equally to this work

${ }^{1}$ Guangxi Botanical Garden of Medicinal Plants, Nanning 530023,

People's Republic of China

Full list of author information is available at the end of the article
}

from it which has a wide range of commercial applications including the production of perfumes, cosmetics, soaps, foods and beverage flavoring [7, 8]. Furthermore, I. verum is the industrial source of shikimic acid, a key intermediate used in the production of Tamiflu, which is a well-known antiviral drug and has recently been used to reduce the effects of bird flu [9]. I. verum has also been reported to possess antioxidant and antimicrobial activities due to its high concentrations of phenol compounds, and it is known that flavonoids also play an important role in this regard [10-12].

Medicinal plant material is used in a large number of phytopharmaceutical industries but the growing demand for these medicines means that the medicinal plant sources might no longer be capable of providing enough material in the future. However, the rich extracts from the $I$. verum biomass have traditionally been considered as waste because of inefficient extraction and separation processes [3], and usually the residues are treated as waste. A great number of innovative extraction methods such as ultrasound-assisted extraction, supercritical 
fluid extraction, extrusion and microwave extraction are now employed in the food industry [8]. Enzyme-assisted extraction is a mild, efficient and environmental friendly extraction method and it has been adopted for extracting various kinds of compounds recently [13]. The ultrasound-assisted extraction technique causes collapse of cavitation bubbles which generates sufficient energy to give rise to collisions between suspended plant particles for accelerating the release, diffusion and dissolution of active substances in the cell. On the other hand, enzymeassisted extraction uses enzyme preparations either alone or in mixtures that catalyze hydrolysis of the cytoderm and glycoproteins, and enhance the release of bioactive substances by disrupting plant cells [14]. Enzymolysisultrasonic assisted extraction is a combined extraction method, which has advantages of the two extraction methods such as mild extraction conditions, lower investment costs and energy requirements, and simplified manipulation [15].

Recently, response surface methodology (RSM), which is a statistical technique to determine the influences of individual factors and their interactive influences, has been used increasingly to optimize processing parameters $[8,16-18]$. In some previous reports, the optimization studies on enzymolysis-ultrasonic assisted extraction of Cucurbita moschata, Lycium barbarum, Momordica charabtia, wheat bran and corn silk have been performed using RSM $[13-15,19,20]$. Hence, the cellulase-ultrasonic assisted extraction technology for flavonoids from plants, combining the mild bio-enzymatic hydrolysis conditions and the rapid ultrasonic extraction technology, will protect the maximum bio-activity of the flavonoids. In this paper, we studied the optimization of cellulase-ultrasonic assisted extraction for flavonoids from $I$. verum residues using response surface methodology. The adsorption conditions were optimized from a single factor and orthogonal design experiments and desorption conditions were optimized from dynamic desorption experiments.

\section{Experimental}

\section{Materials}

The dried fruits of $I$. verum Hook. f. were collected from Baise County, Guangxi, China. A voucher specimen of this material was deposited in the herbarium of the Guangxi Botanical Garden of Medicinal Plants.

Cellulase was purchased from Sigma Company (USA, No. SC118401). Rutin used as the control was obtained from Sinopharm Chemical Reagent Co., Ltd (China, No. U1606503). Ethanol, methanol, petroleum ether were bought from Guangdong Xilong Chemical Factory (China). Hydrochloric acid was from Shanghai Ailian Chemical Reagent Company (China) and sulfuric acid was from Tianjing Qingfa Chemical Factory. Other reagents used in the experiments were purchased from Sinopharm Chemical Reagent Co., Ltd (China).

\section{Methodologies \\ Sample preparation}

$1 \mathrm{~kg}$ dried plant materials was powdered with a mill (Fz02, Zhejiang Baile Mill Factory). After drying at $60^{\circ} \mathrm{C}$ for $12 \mathrm{~h}, 0.9 \mathrm{~kg}$ of crushed material was used for extracting shikimic acid by a water extraction method [21], and then the residues were degreased and decolorized in petroleum ether with a ratio of $1: 3(\mathrm{~m} / \mathrm{v})$ at $60{ }^{\circ} \mathrm{C}$, and carried on a backflow for $4 \mathrm{~h}$. Subsequently, the residue product was dried at $60{ }^{\circ} \mathrm{C}$ for $48 \mathrm{~h}$ and weighed, then stored in a desiccator in order to maintain a constant weight for use in the subsequent experiments. The weight of the residue product was $0.8865 \mathrm{~kg}$, which accounted for $98.5 \%$ of the raw crushed materials.

\section{Identification of flavonoids}

An appropriate amount of the prepared samples was reflux with $80 \%$ ethanol at a solid liquid ratio of 1:10 (m/v) at $80^{\circ} \mathrm{C}$ for $2 \mathrm{~h}$. The ethanol solution was concentrated by reducing the pressure and dried by vacuum. The total flavonoid extracts obtained were dissolved in methanol and then tested using the $\mathrm{HCl}-\mathrm{Mg}$ reaction and the aluminum chloride colorimetric methods. The extracts responded positively to these characteristic color reactions for flavonoids.

\section{Standard curve preparation}

$5.0 \mathrm{mg}$ of rutin was dissolved in $60 \%$ ethanol to a concentration of $0.2 \mathrm{mg} / \mathrm{mL}$ for use as the rutin standard solution. A set of standard solutions containing $0,0.08$, $0.16,0.24,0.32,0.4$ and $0.48 \mathrm{mg}$ of rutin were made up in a total of $5 \mathrm{~mL}$ of $60 \%$ ethanol. $0.4 \mathrm{~mL}$ of $5 \% \mathrm{NaNO}_{2}$ solution was added to each tube, which was incubated and shaken for $6 \mathrm{~min}$, and then $0.4 \mathrm{~mL}$ of $5 \% \mathrm{Al}\left(\mathrm{NO}_{3}\right)_{3}$ solution was added and shaken for a further $6 \mathrm{~min} .4 \mathrm{~mL}$ of $4 \% \mathrm{NaOH}$ solution was added and this was made up to $10 \mathrm{~mL}$ with $60 \%$ ethanol. After incubation for $15 \mathrm{~min}$, the rutin standard solutions with extracted flavonoids were developed by addition of a $\mathrm{Na}_{2} \mathrm{NO}_{2}-\mathrm{Al}\left(\mathrm{NO}_{3}\right)_{3}-\mathrm{NaOH}$ coloration system. This was the read at the wavelength range of $200-700 \mathrm{~nm}$ on an ultraviolet spectrophotometer. The absorbance was measured at $500 \mathrm{~nm}$ which is the selected maximum absorption wavelength and a standard curve was created.

\section{Determination of optimum conditions for extraction of flavonoids}

$1.000 \mathrm{~g}$ of the prepared residue samples was soaked with $5 \mathrm{~mL}$ cellulose in a $50 \mathrm{~mL}$ centrifuge tube and citrate 
buffer was used to adjust $\mathrm{pH}$. The enzymatic hydrolysis was conducted at a constant temperature and $\mathrm{pH}$ for several hours. After inactivating the cellulose at $100{ }^{\circ} \mathrm{C}$ for $5 \mathrm{~min}, 15 \mathrm{~mL}$ ethanol was added and the mixture was subjected to ultrasonic treatment. The extraction process was designed with these corresponding conditions. Using the following conditions of $10 \mathrm{mg} / \mathrm{mL}$ cellulase, $50 \%$ ethanol, a mesh size of $0.355-0.85 \mathrm{~mm}, 2 \mathrm{~h}$ of enzymatic hydrolysis at $\mathrm{pH} 5$, a liquid-solid ratio of 20:1, $60 \mathrm{~min}$ of sonication time and $40{ }^{\circ} \mathrm{C}$, extraction temperature, the extraction yield of flavonoids from the $I$. verum residues was determined. Each of the parameters was kept as above while the others were varied as follows: cellulase concentrations $(2,6,10,14$ and $18 \mathrm{mg} / \mathrm{mL})$, ethanol concentrations $(10,15,20,25,30$ and $50 \%)$, mesh sizes (0.85-2.0, $0.355-0.85,0.25-0.355$ and $0.18-0.25 \mathrm{~mm})$, enzymatic hydrolysis times $(0.5,1,1.5,2,2.5$ and $3 \mathrm{~h}$ ), $\mathrm{pH}(3,4,5,6$ and 7), different liquid-solid ratios (5:1, $10: 1,15: 1,20: 1,25: 1$ and 30:1), sonication times $(15,30$, $45,60,75$ and $90 \mathrm{~min}$ ) and extraction temperatures (35, $40,45,50,55,60$ and $65^{\circ} \mathrm{C}$ ). All tests were carried out in triplicate.

\section{Response surface optimization design Determination of main experimental factors}

On the basis of the single factor determinations of extraction experiments, we selected a set of experimental factors. The main experimental factors were further subjected to selection by the Plackett-Burman design in order to simplify the subsequent response surface experimental design.

\section{Optimization by Box-Benhnken design}

According to the principles of the Box-Benhnken design, the main experimental factors that affect the extraction process of flavonoids from residues of $I$. verum samples were optimized and the response surface analysis was carried out. The relationship between the extraction yield and each factor was established.

\section{Data analysis}

Results were analyzed in triplicate and expressed as mean \pm standard deviation. The data were analyzed by DPS statistical software and $p<0.05$ was considered to be statistically significant.

\section{Results and discussion}

\section{Standard curve and regression equation}

The absorbance was measured at the wavelength of $500 \mathrm{~nm}$ and the standard curve of rutin is shown in Fig. 1. Using the linear least square approach, the regression equation between the concentration and absorbance of rutin standard solutions was obtained as,

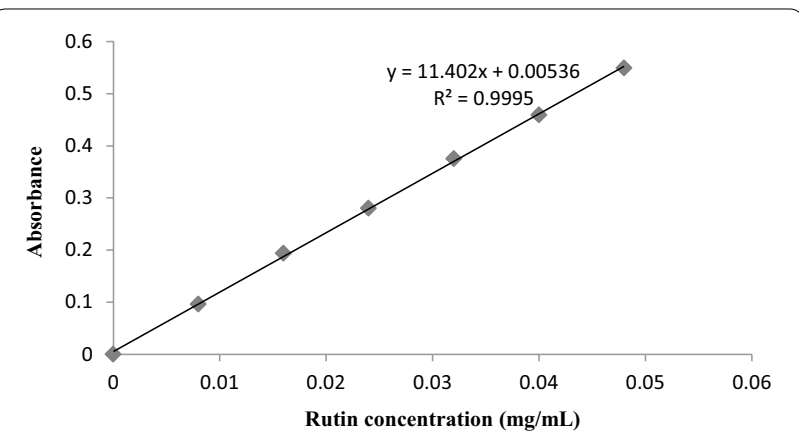

Fig. 1 Standard curve

$A=11.402 C+0.00536\left(R^{2}=0.9995\right)$. Its linear range is from 0.008 to $0.048 \mathrm{mg} / \mathrm{mL}$. The linear calibration was performed to enable quantification of the flavonoids. The extraction yield of flavonoids from the samples was calculated as the percentage of the content according to the following equation:

$$
\text { Extraction yield }(\%)=\frac{C \times V}{m} \times 100 \%
$$

where $A$ is absorbance, $C$ is concentration of flavonoids $(\mathrm{mg} / \mathrm{mL}), V$ is volume of solution $(\mathrm{mL})$, and $m$ is content of the test sample (mg).

\section{Single factor experiment Effect of sonication time on the extraction yield}

Starting from $15 \mathrm{~min}$, the extraction yield increased with an increase of sonication time and reached the maximum value of $11.16 \%$ at $60 \mathrm{~min}$, and then it decreased gradually (Fig. 2). This may be due to low stability of some flavonoids which degraded due to ultrasonic heat effects, and may further result in destruction of their basic structures. The optimum ultrasonic processing time for extracting the flavonoids was determined to be $60 \mathrm{~min}$.

\section{Effect of liquid-solid ratio on the extraction yield}

Figure 3 reveals that the extraction yield of flavonoids was raised with an increased amount of the extracting agent initially from $5 \mathrm{~mL}$ and reached the maximum value of $14.63 \%$ at the liquid-solid ratio of $20: 1$ after which it levelled off. When the liquid-solid ratio was too low, the flavonoids cannot be extracted adequately from the lysed cells. However, when ratio is too high, this will weaken the effect of ultrasonic waves on the fragmentation of the sample. Therefore, the liquid-solid ratio of 20:1 was selected.

\section{Effect of ethanol concentration on the extraction yield}

The effect of ethanol on flavonoids extraction was investigated from 30 to $80 \%$. It is seen in Fig. 4 that different 


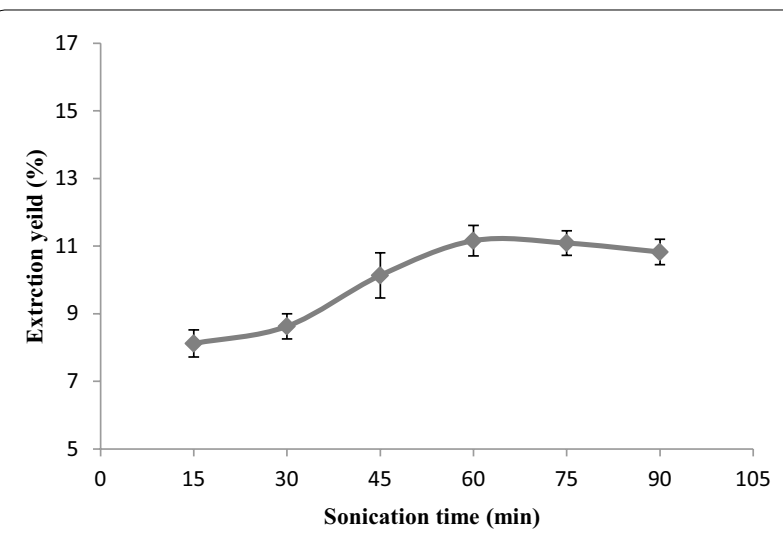

Fig. 2 The effect of sonication times on the extraction yield of flavonoids

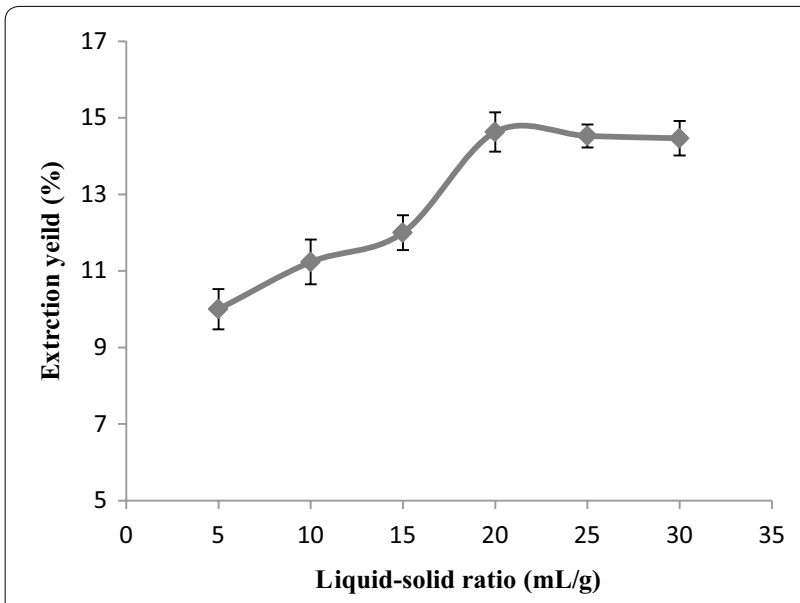

Fig. 3 The effect of liquid-solid ratios on the extraction yield of flavonoids

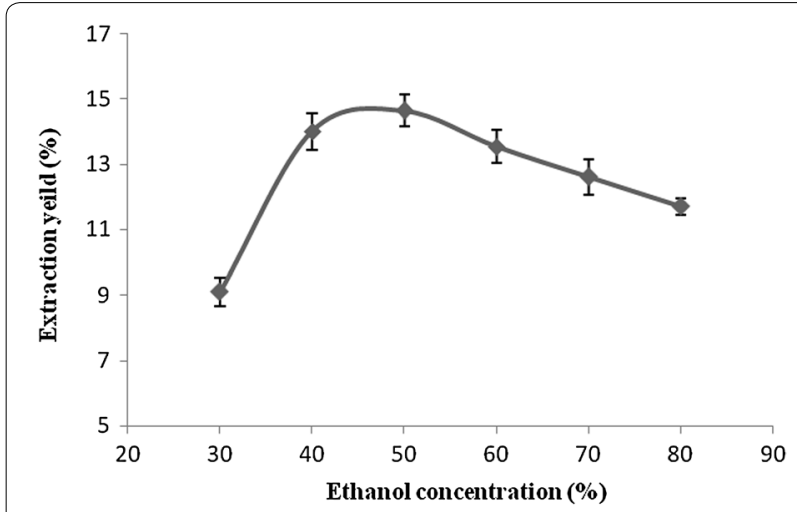

Fig. 4 The effect of ethanol concentrations on the extraction yield of flavonoids concentrations of ethanol have an impact on the flavonoids extraction yield. Low or high concentrations of ethanol are not conducive to the optimum extraction and this is related to the type of flavonoids present in the sample. The flavonoid glycoside components with less polar portions are soluble in ethanol, however, those that are more polar are soluble in water. So when the ethanol concentration reaches the correct proportion, the total flavonoids extraction yield reached the highest value. The experimental results showed that $50 \%$ ethanol was the optimal concentration to extract the flavonoids from the samples.

\section{Effect of enzymatic hydrolysis $\mathrm{pH}$ on the extraction yield}

Figure 5 shows that in the range of $\mathrm{pH}$ from 3 to 7 , the extraction yield was raised below $\mathrm{pH} 5$ and reached the maximum extraction yield of $15.42 \%$ at pH 5 and then it declined as it neared a neutral $\mathrm{pH}$. This can be explained by the fact that the enzymatic hydrolysis $\mathrm{pH}$ had an effect on the cell wall with respect to the hydrolysis of cellulase. Reaction conditions with too much acid or alkali will lead to a loss of biological enzyme activity, and also increase the loss of other non-flavonoids ingredients, so those conditions are not conducive to the extraction of the target components.

\section{Effect of extraction temperature on the extraction yield}

Figure 6 shows that from 35 to $45{ }^{\circ} \mathrm{C}$, the flavonoids extraction yield increased with a rise of the enzymatic extraction temperature, and the peak yield $(15.73 \%)$ was reached at an extraction temperature of $45^{\circ} \mathrm{C}$. When the extraction temperature was higher than $45^{\circ} \mathrm{C}$, the extraction yield kept on decreasing due to the fact that the high extraction temperature always resulted in an increase of

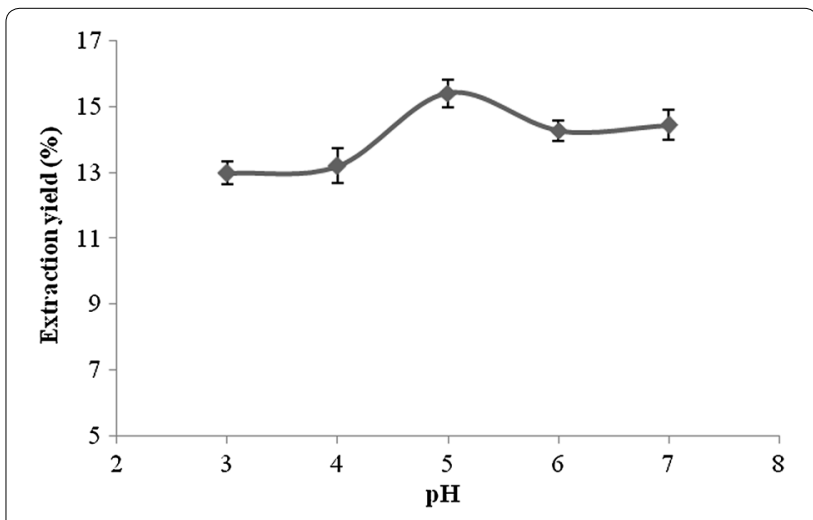

Fig. 5 The effect of $\mathrm{pH}$ on the extraction yield of flavonoids 


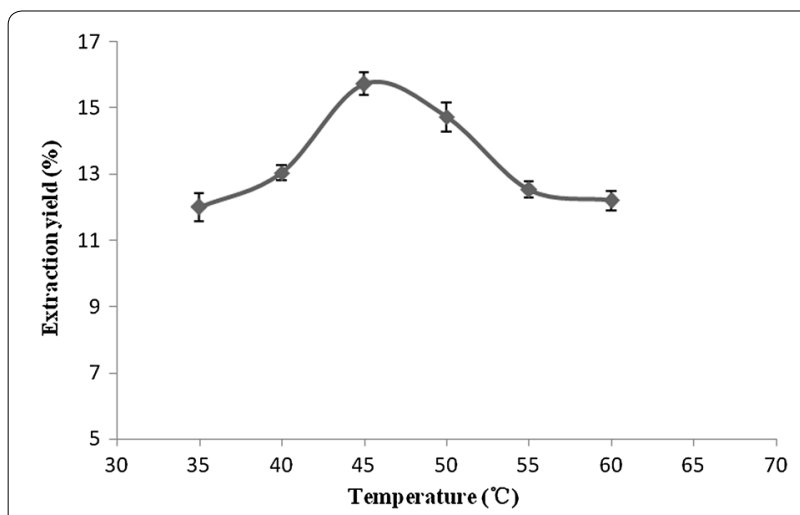

Fig. 6 The effect of temperatures on the extraction yield of flavonoids

enzyme activity $[19,20]$. Therefore, it can be considered that the optimum reaction temperature for enzymatic hydrolysis of the cell wall of $I$. verum is at $45^{\circ} \mathrm{C}$.

\section{Effect of cellulase concentration on the extraction yield}

It is seen in Fig. 7 that the flavonoids extraction yield increased with a rise in the concentration of cellulase. When the concentration was higher than $70 \mathrm{mg} / \mathrm{g}$, the extraction yield dropped instead of increased. This means the cellulase concentration of $70 \mathrm{mg} / \mathrm{g}$ is high enough, and a higher concentration up to $70 \mathrm{mg} / \mathrm{g}$ did not further improve the extraction yield. It may be the viscous enzyme solution with high concentrations of cellulase is not conducive to the enzymatic reaction process.

\section{Effect of enzymatic hydrolysis time on the extraction yield}

It can be seen in Fig. 8 that the extraction yield is increased with a longer time of cellulase enzymatic hydrolysis, while after $2 \mathrm{~h}$, the extraction yield levelled off. Therefore it seems that the enzymatic hydrolysis reaction completely destroyed the cell wall of the sample and

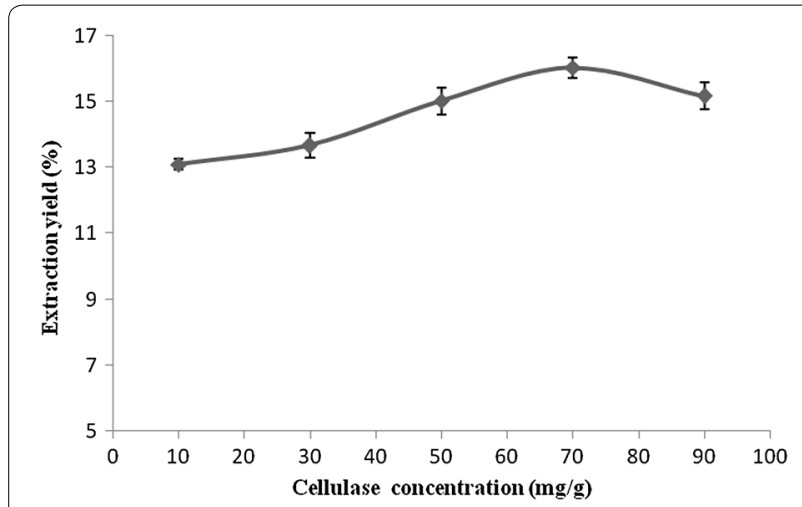

Fig. 7 The effect of concentrations of cellulase on the extraction yield of flavonoids

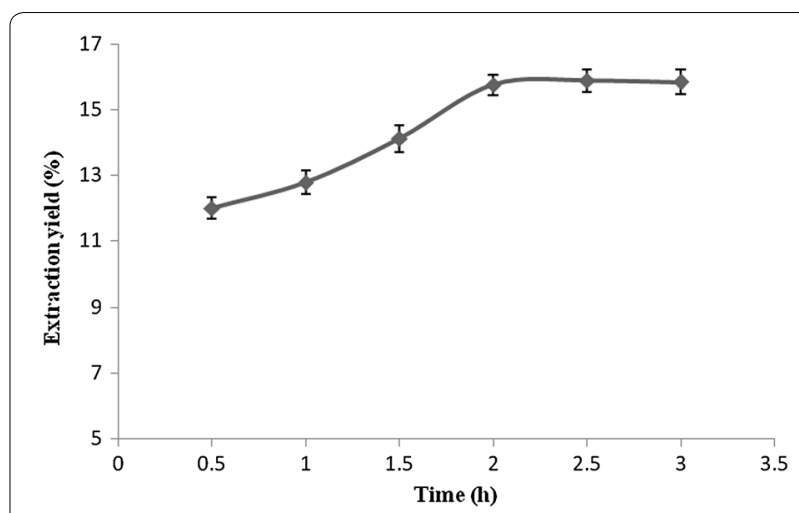

Fig. 8 The effect of times of enzymatic hydrolysis on the extraction yield of flavonoids

released the maximum flavonoids composition within $2 \mathrm{~h}$ of incubation.

\section{Effect of crushed mesh size on the extraction yield}

As shown in Fig. 9, the crushed mesh size $0.355-0.85 \mathrm{~mm}$ is the optimum one to use under these conditions. It can be seen that improving the ability to crush raw materials will lead to an increased rate of flavonoids extraction, while high degrees of crushing will reduce the extraction yield. It might be that high degrees of grinding the raw materials will make the samples become more prone to stick into small groups and this may not be conducive to the enzymatic hydrolysis reaction and subsequent ultrasound extraction.

\section{Response surface methodology and results analysis Plackett-Burman design and data analysis}

Plackett-Burman design and data analysis can be seen in Tables 1 and 2. The individual factors of sonication time (A), liquid-solid ratio (B), ethanol concentration (C), $\mathrm{pH}$

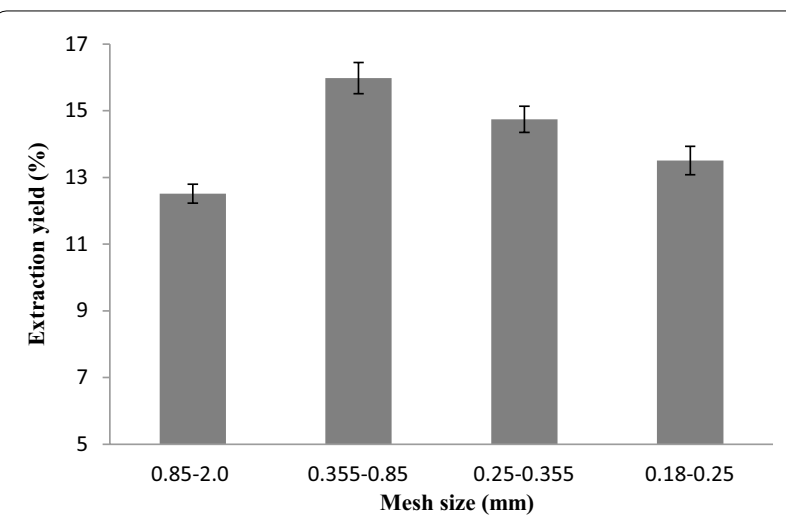

Fig. 9 The effect of crushed mesh sizes on the extraction yield of flavonoids 
Table 1 Scheme and experimental results of Plackett-Burman design

\begin{tabular}{|c|c|c|c|c|c|c|c|c|}
\hline No. & $A(\min )$ & $B(\mathrm{~mL} / \mathrm{g})$ & C (\%) & D & $\mathrm{E}\left({ }^{\circ} \mathrm{C}\right)$ & $F(\mathrm{mg} / \mathrm{g})$ & G (h) & $\mathrm{Y}(\%)$ \\
\hline 1 & 75 & 15 & 60 & 4 & 40 & 50 & 2.5 & 9.89 \\
\hline 2 & 75 & 25 & 60 & 4 & 50 & 90 & 1.5 & 11.78 \\
\hline 3 & 75 & 15 & 40 & 6 & 50 & 90 & 1.5 & 7.96 \\
\hline 4 & 75 & 25 & 40 & 6 & 40 & 50 & 1.5 & 10.51 \\
\hline 5 & 45 & 15 & 60 & 6 & 40 & 90 & 1.5 & 10.81 \\
\hline 6 & 45 & 25 & 60 & 6 & 40 & 90 & 2.5 & 11.56 \\
\hline 7 & 75 & 15 & 60 & 6 & 50 & 50 & 2.5 & 13.05 \\
\hline 8 & 45 & 25 & 40 & 6 & 50 & 50 & 2.5 & 10.81 \\
\hline 9 & 45 & 15 & 40 & 4 & 40 & 50 & 1.5 & 7.70 \\
\hline 10 & 45 & 15 & 40 & 4 & 50 & 90 & 2.5 & 6.95 \\
\hline 11 & 45 & 25 & 60 & 4 & 50 & 50 & 1.5 & 11.50 \\
\hline 12 & 75 & 25 & 40 & 4 & 40 & 90 & 2.5 & 9.15 \\
\hline
\end{tabular}

Table 2 Variance analysis of Plackett-Burman design

\begin{tabular}{|c|c|c|c|c|c|}
\hline Source & Sum of squares & Degree of freedom & Mean square & $F$-value & $p$ value \\
\hline Regression model & 35.31 & 7 & 5.04 & 7.69 & 0.0335 \\
\hline A & 0.75 & 1 & 0.75 & 1.14 & 0.3449 \\
\hline B & 6.64 & 1 & 6.64 & 10.13 & 0.0335 \\
\hline C & 20.03 & 1 & 20.03 & 30.55 & 0.0052 \\
\hline D & 4.99 & 1 & 4.99 & 7.61 & 0.0509 \\
\hline E & 0.49 & 1 & 0.49 & 0.75 & 0.4341 \\
\hline $\mathrm{F}$ & 2.29 & 1 & 2.29 & 3.49 & 0.1350 \\
\hline G & 0.11 & 1 & 0.11 & 0.17 & 0.7006 \\
\hline
\end{tabular}

(D), temperature (E), cellulase concentration $(F)$, enzymatic hydrolysis time $(\mathrm{G})$ and extraction yield $(\mathrm{Y})$ were used. As shown in Table 2, the $p$ value of the regression model is $<0.05$, which indicates that the results from the model are significant. For each of the experimental factors, the level of significance was C, B, D, F, A, E and G in that order. Since the ethanol concentration (C), liquidsolid ratio (B) and $\mathrm{pH}(\mathrm{D})$ have higher significant effects than the other factors, they were selected as the main optimization experimental factors for further response surface analysis.

\section{Box-Benhnken design and data analysis}

Using the basic of Plackett-Burman design, we selected the main optimization experimental factors and levels for analysis by Box-Benhnken response surface design and show the results in Table 3. Other factors levels that were used are sonication time of $60 \mathrm{~min}$, a temperature of $45{ }^{\circ} \mathrm{C}$, a cellulase concentration of $70 \mathrm{mg} / \mathrm{g}$ and an enzymatic hydrolysis time for $2 \mathrm{~h}$.

The analysis of variance for Box-Benhnken response surface design can be seen in Table 4. The regression
Table 3 The factor coding and levels of the Box-Benhnken design

\begin{tabular}{lllcrr}
\hline Factors & Real value & Coding & \multicolumn{3}{l}{ Levels } \\
\cline { 3 - 6 } & & & \multicolumn{1}{c}{$\mathbf{1}$} & \multicolumn{1}{c}{$\mathbf{0}$} & $\mathbf{1}$ \\
\hline C & $X_{1}$ & $x_{1}$ & 40 & 50 & 60 \\
B & $X_{2}$ & $x_{2}$ & 15 & 20 & 25 \\
D & $x_{3}$ & $x_{3}$ & 4 & 5 & 6 \\
\hline
\end{tabular}

$x_{1}=\left(\mathrm{X}_{1}-50\right) / 10 ; x_{2}=\left(\mathrm{X}_{2}-20\right) / 5 ; x_{3}=\left(\mathrm{X}_{3}-5\right) / 1$

equation for the extraction yield of flavonoids and the relevant analysis items are shown in the formula below:

$$
\begin{aligned}
\mathrm{Y}(\%)= & -55.90654+1.73559 \mathrm{X}_{1}+1.73800 \mathrm{X}_{2} \\
& +2.97425 \mathrm{X}_{3}-0.010872 \mathrm{X}_{1} \mathrm{X}_{2} \\
& -9.98845 \mathrm{E}-003 \mathrm{X}_{1} \mathrm{X}_{3}+0.055244 \mathrm{X}_{2} \mathrm{X}_{3} \\
& -0.014268 \mathrm{X}_{1}^{2}-0.035944 \mathrm{X}_{2}^{2}-0.33907 \mathrm{X}_{3}^{2}
\end{aligned}
$$

where $\mathrm{Y}$ is the extraction yield of flavonoids (\%), $\mathrm{X}_{1}$ is the ethanol concentration (\%), $\mathrm{X}_{2}$ is the liquid-solid ratio $(\mathrm{mL} / \mathrm{g})$ and $\mathrm{X}_{3}$ is the $\mathrm{pH}$. 
Table 4 Observed and estimated values of Box-Benhnken response surface design

\begin{tabular}{lrrrrl}
\hline No. & $\mathbf{C}(\%)$ & $\mathbf{B}(\mathbf{m L} / \mathbf{g})$ & $\mathbf{D}$ & $\mathbf{Y}(\%)$ & $\begin{array}{l}\text { Estimated } \\
\text { value }(\%)\end{array}$ \\
\hline 1 & 1 & 1 & 0 & 12.66 & 12.60 \\
2 & 0 & 0 & 1 & 13.02 & 12.65 \\
4 & -1 & -1 & 0 & 10.58 & 10.69 \\
5 & 1 & 1 & 0 & 11.95 & 11.84 \\
6 & 0 & 0 & 0 & 13.92 & 14.13 \\
7 & 0 & 0 & 0 & 13.38 & 14.13 \\
8 & -1 & -1 & 0 & 12.05 & 12.10 \\
9 & 1 & 1 & -1 & 12.96 & 12.69 \\
10 & 1 & 1 & 1 & 12.44 & 12.87 \\
11 & 0 & 0 & 0 & 14.44 & 14.13 \\
12 & 0 & 0 & 0 & 14.14 & 14.13 \\
13 & 0 & 0 & 1 & 13.85 & 13.53 \\
14 & -1 & -1 & -1 & 12.09 & 11.67 \\
15 & 0 & 0 & -1 & 14.79 & 14.13 \\
16 & 0 & 1 & -1 & 12.22 & 12.60 \\
17 & 0 & -1 & -1 & 12.50 & 12.82 \\
\hline
\end{tabular}

The analysis of variance of the regression model were evaluated using the corresponding $F$ and $p$ values, and presented in Table 5. As shown in Table 5, the $\mathrm{F}$ value is calculated to be 6.05 and the $\mathrm{p}$ value is 0.0135 , which suggests that the model is statistically significant. The model's coefficient of determination $\left(R^{2}\right)$ is 0.9871 , which indicates that more than $98.71 \%$ of the response variability is explained by the model. The quadratic terms $\mathrm{X}_{1}^{2}$ and $\mathrm{X}_{2}^{2}$ are significant $(p<0.05)$, while, the interaction terms and linear terms are not significant $(p>0.05)$. This indicates that the extraction yield and relevant analysis items have obvious surface relationships, and interactions among each experimental factor are not significant. The lack of fit is not significant $(p>0.05)$, which means the regression equation may fit the actual situation. The response surface and contour plots of the ethanol concentration, liquid-solid ratio and enzymatic hydrolysis $\mathrm{pH}$ are shown in Figs. 10, 11 and 12.

\section{Results of response surface optimization and verification tests}

The optimum extraction conditions via response surface optimization are as follows: the ethanol concentration, $\mathrm{X}_{1}=51.14 \%$, the liquid-solid ratio, $\mathrm{X}_{2}=20.52 \mathrm{~mL} / \mathrm{g}$, the enzymatic hydrolysis $\mathrm{pH}, \mathrm{X}_{3}=5.303$, and the estimated optimal extraction yield is $14.20 \%$. The optimal experimental conditions were carried out on three repeated experiments to optimize and verify the reliability of the conditions used, and the levels of the other factors were as follows: sonication time was $60 \mathrm{~min}$, enzymolysis temperature was $45^{\circ} \mathrm{C}$, enzyme concentration was $70 \mathrm{mg} / \mathrm{g}$, enzymatic hydrolysis time was $2 \mathrm{~h}$ and the crushed mesh number was $0.355-0.85 \mathrm{~mm}$. The test results are shown in Table 6.

The results of the validation test show that the RSD of the extraction yield is less than $5 \%$, and the average extraction yield is $14.76 \%$, which is near equivalent to the maximum extraction yield of $14.79 \%$ seen in previous experiments listed in Table 4. It is concluded that this method is both effective and feasible.

Under the uniform extraction conditions of ultrasonic treatment $60 \mathrm{~min}$, a liquid-solid ratio of $20.52 \mathrm{~mL} / \mathrm{g}$ and

Table 5 Variance analysis of regression equation for the extraction yield

\begin{tabular}{|c|c|c|c|c|c|}
\hline Source & Sum of squares & Degree of freedom & Mean square & $F$-value & $p$ value \\
\hline Regression model & 16.90 & 9 & 1.88 & 6.05 & $0.0135^{*}$ \\
\hline$x_{1}$ & 1.37 & 1 & 1.37 & 4.42 & 0.0737 \\
\hline$x_{2}$ & 0.22 & 1 & 0.22 & 0.70 & 0.4320 \\
\hline$x_{3}$ & 0.29 & 1 & 0.29 & 0.92 & 0.3693 \\
\hline$x_{1} x_{2}$ & 1.18 & 1 & 1.18 & 3.81 & 0.0920 \\
\hline$x_{1} x_{3}$ & 0.04 & 1 & 0.04 & 0.13 & 0.7305 \\
\hline$x_{2} x_{3}$ & 0.31 & 1 & 0.31 & 0.98 & 0.3544 \\
\hline$X_{1}^{2}$ & 8.57 & 1 & 8.57 & 27.62 & $0.0012^{*}$ \\
\hline$x_{2}^{2}$ & 3.40 & 1 & 3.40 & 10.95 & $0.0129^{*}$ \\
\hline$X_{3}^{2}$ & 0.48 & 1 & 0.48 & 1.56 & 0.2519 \\
\hline Residual error & 2.17 & 7 & 0.31 & & \\
\hline Lack of Fit & 1.04 & 3 & 0.35 & 1.23 & 0.4088 \\
\hline Pure error & 1.13 & 4 & 0.28 & & \\
\hline \multirow[t]{2}{*}{ Total } & 19.08 & 16 & & & \\
\hline & $R^{2}=0.9871$ & & & & \\
\hline
\end{tabular}

* Means significant $(p<0.05)$ 


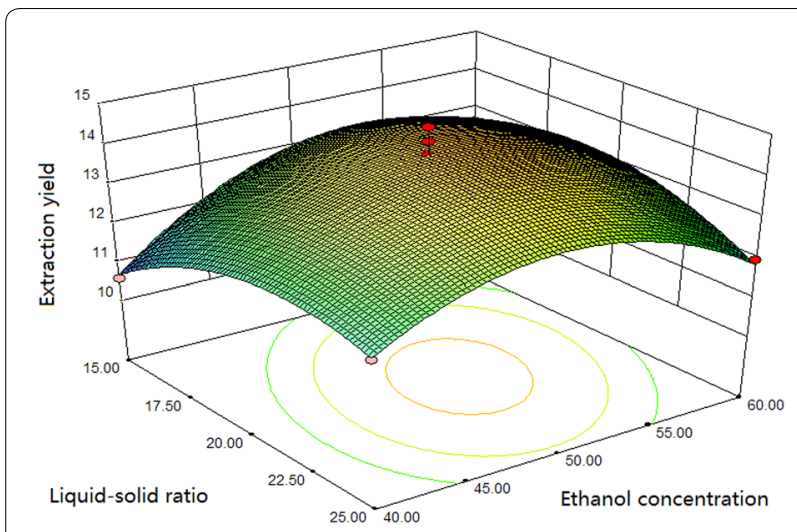

Fig. 10 Response surface and contour plots showing the effect of ethanol concentration and liquid-solid ratio on the extraction yield

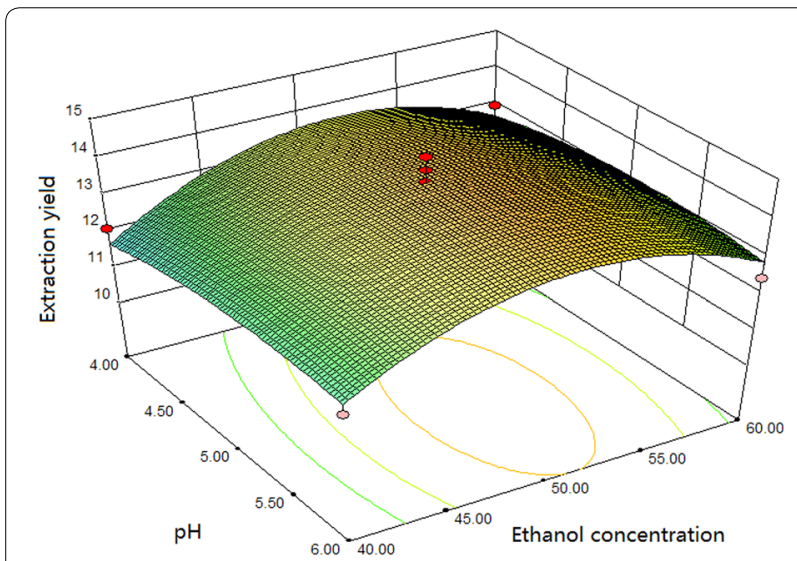

Fig. 11 Response surface and contour plots showing the effect of ethanol concentration and $\mathrm{pH}$ on the extraction yield

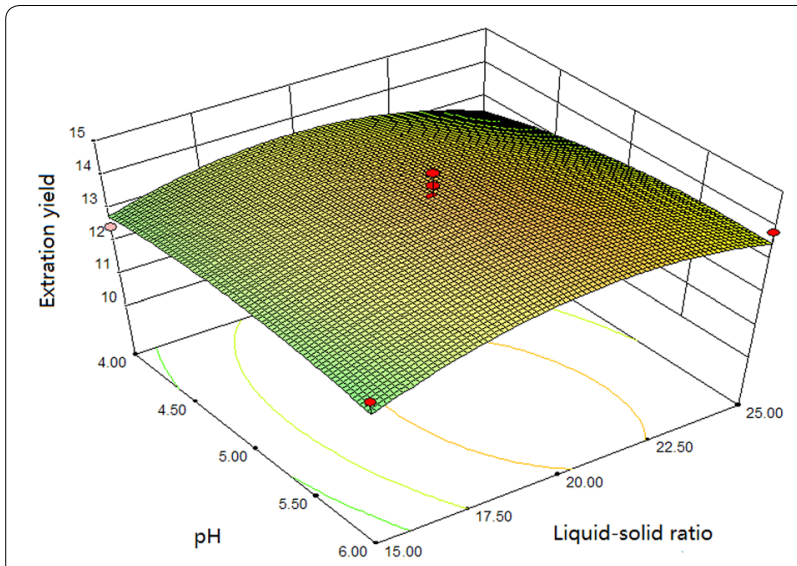

Fig. 12 Response surface and contour plots showing the effect of liquid-solid ratio and $\mathrm{pH}$ on the extraction yield

Table 6 The results of the validation test

\begin{tabular}{llllll}
\hline Test no. & $\mathbf{1}$ & $\mathbf{2}$ & $\mathbf{3}$ & Average & RSD \% \\
\hline Extraction yield (\%) & 14.87 & 14.09 & 15.33 & 14.76 & 4.24 \\
\hline
\end{tabular}

an ethanol concentration of $51.14 \%$, the average of flavonoids extraction yield without enzyme assistance was $10.15 \%(n=3)$, while, with enzyme assistance this was increased to $14.76 \%(\mathrm{n}=3)$ which is effectively a relative increase of $45.42 \%$.

\section{Conclusions}

In this study, a regression model of cellulase-ultrasonic assisted extraction technology for flavonoids from $I$. verum residues was established. Using ethanol concentration, liquid-solid ratio and enzymatic hydrolysis $\mathrm{pH}$ as the independent variables, and the extraction yield of flavonoids as the dependent variable the optimum extraction process was determined. The concentration of ethanol is $51.14 \%$, the liquid-solid ratio is $20.52 \mathrm{~mL} / \mathrm{g}$, the enzymatic hydrolysis $\mathrm{pH}$ is 5.303 , the sonication time is $60 \mathrm{~min}$, the enzyme solution temperature is $45{ }^{\circ} \mathrm{C}$, the amount of added enzyme is $70 \mathrm{mg} / \mathrm{g}$, the enzymatic hydrolysis time is $2 \mathrm{~h}$ and the crushed mesh size is $0.355-$ $0.85 \mathrm{~mm}$. Under these optimum extraction conditions, the maximum flavonoids yield achieved is $14.76 \%$. Thus the data presented here indicate that the cellulase-ultrasonic assisted extraction technology has the potential be used for the industrial production of flavonoids from $I$. verum.

\section{Authors' contributions}

DH designed the study, analyzed the data and statistics, discussed the results and wrote the manuscript. XZ collected the plant samples, confected herbarium, performed the laboratory work, analyzed the data and drafted the paper. JS contributed to preparing the experimental materials and also performed the laboratory work. XG collected and dried the plant samples and performed the laboratory work. SW contributed to designing the study and data analysis, supervised the laboratory work, made conclusions and critically read the manuscript. All authors read and approved the final manuscript.

\section{Author details}

${ }^{1}$ Guangxi Botanical Garden of Medicinal Plants, Nanning 530023, People's Republic of China. ${ }^{2}$ Guangxi Key Laboratory of Medicinal Resources Conservation and Genetic Improvement, Nanning 530023, People's Republic of China.

${ }^{3}$ State Engineering Laboratory of Southwest Endangered Medicinal Resources Development, Nanning 530023, People's Republic of China.

\section{Acknowledgements}

Thanks are due to Dr. Dev Sooranna for editing the English revision of the manuscript and to the China Science-technology Support Plan Project (No.2011BAl01B04) and Guangxi province Science-technology Project (No.14123001-2 and No. 15104002-3-8) for financial support.

\section{Competing interests}

The authors declare that they have no competing interests.

Received: 2 April 2016 Accepted: 6 September 2016

Published online: 14 September 2016

\section{References}

1. Miao JH, Peng Y, Xiao PG (2014) Southern and Pan-southern Medicine. China Press of Traditional Chinese Medicine, Beijing, p 10

2. Yan JH, Xiao XX, Huang KL (2002) Component analysis of volatile oil from Illicium verum Hook. f. J Cent South Univ Technol. 9(3):173-176 
3. Peng W, Lin Z, Chang J, Gu F, Zhu X (2013) Biomedical molecular characteristics of YBSJ extractives from Illicium verum fruit. Biotechnol Biotechno Equip. 27(6):4311-4316

4. Wei LL, Hua RM, Li MY, Huang YZ, Li SG, He YJ, Shen ZH (2014) Chemical composition and biological activity of star anise Illicium verum extracts against maize weevil, Sitophilus zeamais adults. J Insect Sci. 14(2):80

5. Wang GW, Hu WT, Huang BK, Qin LP (2011) Illicium verum: a review on its botany, traditional use, chemistry and pharmacology. J Ethnopharmacol 136:10-20

6. State Pharmacopoeia Committee (2015) Pharmacopoeia of the People's Republic of China. Med Sci Technol Press, Beijing, p 4

7. Li G, Sun Z, Xia L, Shi J, Liu Y, Suo Y, You J (2010) Supercritical $\mathrm{CO}_{2}$ oil extraction from Chinese star anise seed and simultaneous compositional analysis using HPLC by fluorescence detection and online atmospheric Cl-MS identification. J Sci Food Agric 90:1905-1913

8. Lee AY, Kim HS, Choi G, Moon BC, Chun JM, Kin HK (2014) Optimization of ultrasonic-assisted extraction of active compounds from the fruit of star anise by using response surface methodology. Food Anal Meth 7:1661-1670

9. Just J, Deans BJ, Olivier WJ, Paull B, Bissember AC, Smith JA (2015) New method for the rapid extraction of natural products: efficient isolation of shikimic acid from star anise. Org Lett 17:2428-2430

10. Cai M, Guo X, Liang H, Sun P (2013) Microwave-assisted extraction and antioxidant activity of star anise oil from Illicium verum Hook. f. Int J Food Sci Technol 48:2324-2330

11. Chung $\mathrm{H}-\mathrm{J}$ (2009) Evaluation of the biological activity of extracts from star-anise (Illicium verum). J Food Sci Nutr. 14:195-200

12. Luna C, Chávez VHG, Barriga-Castro ED, Núñez NO, Mendoza-Reséndez $R$ (2015) Biosynthesis of silver fine particles and particles decorated with nanoparticles using the extract of Illicium verum (star anise) seeds. Spectrochim Acta Part A 141:43-50
13. Liu Y, Gong G, Zhang J, Jia S, Li F, Wang Y, Wu S (2014) Response surface optimization of ultrasound-assisted enzymatic extraction polysaccharides from Lycium barbarum. Carbohydr Polym 110:278-284

14. Wu H, Zhu J, Diao W, Wang C (2014) Ultrasound-assisted enzymatic extraction and antioxidant activity of polysaccharides from pumpkin (Cucurbita moschata). Carbohydr Polym 113:314-324

15. Chen S, Tian J, Wang J, Wang Y, Xing L (2014) Enzymolysis-ultrasonic assisted extraction, chemical characteristics and bioactivities of polysaccharides from corn silk. Carbohydr Polym 101:332-341

16. Tabaraki R, Nateghi A (2011) Optimization of ultrasonic-assisted extraction of natural antioxidants from rice bran using response surface methodology. Ultrason Sonochem 18:1279-1286

17. Lee WC, Yusof S, Hamid NSA, Baharin BS (2006) Optimizing conditions for enzymatic clarification of banana juice using response surface methodology (RSM). J Food Eng 73:55-63

18. Wang J, Chen Y, Ge X, Yu H (2007) Optimization of coagulation-flocculation process for a paper-recycling wastewater treatment using response surface methodology. Colloids Surf A 302:204-210

19. Fan T, Hu J, Fu L, Zhang L (2015) Optimization of enzymolysis-ultrasonic assisted extraction of polysaccharides from Momordica charabtia L. by response surface methodology. Carbohydr Polym 115:701-706

20. Wang J, Sun B, Liu Y, Zhang H (2014) Optimisation of ultrasound-assisted enzymatic extraction of arabinoxylan from wheat bran. Food Chem 150:482-488

21. Ohira H, Torii N, Aida TM, Watanabe M, Smith RL (2009) Rapid seperation of shikimic acid from Chinese star anise (Illicium verum Hook. f.) with hot water extraction. Sep Purif Technol. 69:102-108

\section{Submit your manuscript to a SpringerOpen ${ }^{\odot}$ journal and benefit from:}

- Convenient online submission

- Rigorous peer review

- Immediate publication on acceptance

- Open access: articles freely available online

- High visibility within the field

- Retaining the copyright to your article

Submit your next manuscript at springeropen.com 